\title{
Notes for Teachers
}

\section{How to use this book}

The philosophy of this book is that the subject of ergonomics and human factors is best taught to engineering students by letting them exercise their skills practically and develop an analytical eye when faced with a real work environment improvement situation - as opposed to learning through rote memorizing and formal exams. Ideally, we encourage teachers to set up the course curriculum to apply the knowledge and topics in this book to a workplace re-design case. This may be a fictive or "real" workplace (meaning tangible and observable; could be in a real industrial workplace or in a lab), where it is possible for students to use data collection and analysis (using the methods in this book) to determine a current state of the workplace, listing improvement potentials. Then, they should use their knowledge of ideal design principles (also in this book) to devise a change project to support human well-being and system performance, and then bring it to a stage of theoretical or practical proof-of-concept that can convince an audience of peers (and the teacher) that the proposal is feasible, from a practical and economic point of view. (This is how we have been teaching the subject, in the form of a seven-week project based on an assembly workstation rigged up in a lab.)

Before this book came into being, its contents had for several years been taught to students in a course at Master of Science level at a Swedish technical university, usually after 2-3 years of production

How to cite this book chapter:

Berlin, C and Adams C 2017 Production Ergonomics: Designing Work Systems to Support Optimal Human Performance. Pp. 259-262. London: Ubiquity Press. DOI: https://doi.org/10.5334/bbe.n. License: CC-BY 4.0 
engineering studies. The course curriculum was based on all students forming groups of four or five and tackling a workplace improvement project like the one briefly described above. All these aspects allowed the students to exercise much of the book's contents (plus those of another book about work design, the classic tome Maynard's Industrial Engineering Handbook (Zandin, 2001); that book covered aspects of productivity measurement, time studies, etc. that are not covered by this book).

This backstory does not exclude a "younger" target audience or a different course setup altogether, but these teachers' notes aim to stimulate the students towards higher levels of cognitive ability (according to Bloom's taxonomy of cognitive abilities; Anderson and Krathwold, 2001), e.g. evaluation, reflection and creation/synthesis, and our experience is that our tried-and-tested improvement project has served this purpose well. At the end of the course, students overall feel that they have grasped the knowledge and are able to act on it independently, thereby making them more capable, analytical and creative as engineers ${ }^{1}$. Another intention is to prepare engineering students to tackle open-ended problems that may be solved in many different ways. This of course requires some self-assurance on the part of the students, as there is no "textbook answer".

On an individual level, the topics can be examined according to the same philosophy as stated above using open-ended essay questions that stimulate students to seek out their own information (e.g. by independently searching for examples, case studies and equipment listings in literature or online) and to use a critical eye to recognize improvement potentials in their own surroundings. This requires the teacher to be observant of the students' analytical approach and process and reflective abilities, rather than simply marking answers as "correct" or "incorrect". This individual research-writing format may be ideal as preparation for discussion seminars. Therefore, the study questions at the end of each topic chapter in this book aim primarily to stimulate students to consider how the knowledge may be applied to a problem scenario.

A further ambition is to have this book serve as a handy reference for students in their future application of ergonomics and human factors in their workplace improvement practice. For this reason we introduce the notion that engineers may take on a number of different roles in their future working life, and that each of those roles may be primarily concerned with analysis and problem solving on many different system levels.

Therefore, it is advisable to alert students to the fact that they are being prepared for a variety of future work-life scenarios, where they themselves may play a variety of roles and will also encounter other roles that may have different priorities and will require different types of evidence to be convinced that an improvement proposal is worthwhile. It is ideal if students are guided towards adopting the perspective of several different stakeholders during the course, in order to understand the main concerns of those stakeholders and be able to communicate with them effectively in the future.

Below, we point out the consistently repeated elements of each chapter, to further clarify their perspective and pedagogical intent:

"Why do I need to know this as an engineer?"
This text aims to appeal to the student's (perhaps fuzzy) idea of what it will be like to work as an engineer in the future, and in particular introduces the scenario of acting as a workplace improvement agent. These short texts discuss how the chapter's knowledge benefits worker performance, productivity and (when applicable) how acting on the knowledge can be a good business case. 


\begin{tabular}{|c|c|}
\hline The Roles & $\begin{array}{l}\text { These "characters" presented in the Introduction re-appear at the beginning of } \\
\text { each topic chapter to further emphasize that improving a workplace is usually } \\
\text { a team effort, with many different work roles put in charge of overlapping areas } \\
\text { of responsibility that can affect workplace ergonomics. The idea is to increase } \\
\text { the awareness that each role may seek different types of "key evidence" to be } \\
\text { convinced that an ergonomics intervention is worthwhile, will have a desired } \\
\text { effect and will target the appropriate concerns. }\end{array}$ \\
\hline Study questions & $\begin{array}{l}\text { Here, a way to approach and absorb the material individually is aided by a few } \\
\text { warm-up questions that guide the student towards seeking the answer in a } \\
\text { particular section in the book, followed by a couple of "look around you" ques- } \\
\text { tions that aim to train their observational, reflective and analytical abilities. An } \\
\text { answer guide is also provided at the end of the book. }\end{array}$ \\
\hline $\begin{array}{l}\text { "Connect this knowledge } \\
\text { to an improvement } \\
\text { project" }\end{array}$ & $\begin{array}{l}\text { Similar to the "Design for..." guidelines, these bullet lists provide specific advice } \\
\text { that encourages students to combine data collection and analysis (as appropri- } \\
\text { ate) during different stages of an improvement project. }\end{array}$ \\
\hline $\begin{array}{l}\text { "Connection to other } \\
\text { topics in this book" }\end{array}$ & $\begin{array}{l}\text { This section indicates the relation and overlap or interaction between the } \\
\text { present chapter and the others in the book; quite often, there are ripple effects of } \\
\text { some aspects of ergonomics that end up affecting multiple other aspects. These } \\
\text { chapter elements reveal the connections. }\end{array}$ \\
\hline Summary & This element serves as a quick reminder of the scope that each chapter covers. \\
\hline "Design for..." & $\begin{array}{l}\text { Compiled in Part } 3 \text {, these bullet lists offer the student a checklist of "design ide- } \\
\text { als" that can be useful if an ergonomics intervention is meant to target specific } \\
\text { improvement potentials. It is advisable to have students study these and make } \\
\text { sure they can explain the underlying theoretical reasons why the recommenda- } \\
\text { tions are good advice. }\end{array}$ \\
\hline
\end{tabular}

\section{Notes}

1 The ideal level of knowledge, skills and competence that we want this book to support corresponds to the European Qualifications Framework (EQF) levels 3 to 6 (European Commission, 2016). However, these levels can only be truly supported through a well-planned curriculum, and should not be expected as a result of merely reading this book.

\section{References}

Anderson, L. \& Krathwohl, D. (2001). A Taxonomy for Learning, Teaching, and Assessing: A Revision of Bloom's Taxonomy of Educational Objectives. New York: Longman.

European Commission. (2016). Descriptors defining levels in the European Qualifications Framework. [Online] Available from: https://ec.europa.eu/ploteus/en/content/descriptors-page [Accessed 20 June 2016].

Zandin, K. B. (2001). Maynard's Industrial Engineering Handbook, 5th Edition. [Online] New York: McGraw Hill. Available from: http://accessengineeringlibrary.com/browse/ maynards-industrialengineering-handbook-fifth-edition/p2000a1fc99706.9001 [Accessed 16 January 2014]. 
